\title{
Living in Rural Areas of Peninsular Malaysia: Risk Factor for Goitre
}

\author{
Shahar $M A^{a}$, Omar $A M^{b}, A B$ Wahab $N^{c}$, Sukor $N^{c}$, Kamaruddin $N A^{c}$ \\ ${ }^{a}$ AVISENA Specialist Hospital, Shah Alam, Selangor \\ bDepartment of Internal Medicine, Kulliyyah of Medicine, International Islamic University Malaysia (IIUM), \\ Kuantan, Pahang \\ 'Endocrine Unit, Universiti Kebangsaan Malaysia Medical Centre (UKMMC), Jalan Yaakob Latiff, Bandar Seri \\ Permaisuri, Kuala Lumpur.
}

\section{ABSTRACT}

Introduction: Thyroid disorders are among common medical conditions encountered in clinical practice. However, the disease burden among Malaysian population has not been established. This study was aimed to determine the prevalence of goitre and its associated factors among adult population in Peninsular Malaysia. Materials and Methods: A cross-sectional study was performed in 5 pre-assigned regions in Peninsular Malaysia. Participants' sociodemographic profile and medical history were recorded. Physical examinations were done looking for abnormalities of the thyroid gland and signs of thyroid dysfunctions. The diagnosis of goitre was made by palpation and corroborated by the repeat examination by another investigator. The World Health Organization (WHO) goitre grading system was used. Fifteen millilitre of blood were withdrawn and analysed at a central laboratory. Results: Among 2190 respondents, the prevalence of goitre was $9.3 \%$. Goitre was associated with positive anti-thyroperoxidase and anti-thyroglobulin antibodies. Females were at higher risk of goitre (adjusted $\mathrm{OR}=2.4 ; 95 \% \mathrm{Cl} 1.6-3.5 ; \mathrm{p}<0.001$ ). The other risk factors of goitre were Indian ethnicity (adjusted $\mathrm{OR}=2.0 ; 95 \% \mathrm{Cl} 1.2-3.3 ; \mathrm{p}=0.006$ ), positive anti-thyroperoxidase (adjusted OR=1.8; 95\% $\mathrm{Cl} 1.1-3.1 ; \mathrm{p}=0.024$ ) and living in rural area (adjusted $\mathrm{OR}=1.7 ; 95 \% \mathrm{Cl} 1.2-2.5 ; \mathrm{p}=0.002$ ). These areas had been shown to suffer from some degree of iodine insufficiency in the past. Conclusions: The prevalence of goitre in Peninsular Malaysia was comparable with other studies. The main predictors of thyroid disorders are female gender and thyroid antibodies. Living in rural areas was associated with goitre.

KEYWORDS: Goitre, anti-TG, anti-TPO

\section{INTRODUCTION}

Goitre is a common sign of thyroid disorders and dysfunction. In recent years the diagnosis of goitre has increased due to the advent of ultrasonography. The prevalence of goitre from various studies ranges between 7.0 and 15.5\%. ${ }^{1-6}$ Apart from the population characteristics, the differences in the prevalence reported in these studies could be explained by the availability of iodine. In areas of persistent iodine deficiency, the prevalence

Corresponding author:

Assoc. Prof. Dr. Mohammad Arif Shahar

AVISENA Specialist Hospital

4, Jalan Ikhtisas, Seksyen 14

40000, Shah Alam, Selangor

Tel : +6012-7802361

Email: arifshahar2013@gmail.com of goitre was much higher. ${ }^{7}$ On the other hand, repletion of iodine contributes to reduction of goitre. However, in places of iodine excess the prevalence of thyroid nodules have increased. ${ }^{5}$

In Malaysia, the most recent population studies on goitre were conducted in 1990's. These studies were mainly aimed at looking at the prevalence of endemic goitre and iodine deficiency. ${ }^{8-11}$ They were mainly conducted in rural areas of the Peninsular Malaysia and East Malaysia involving indigenous populations. Another study done in a tertiary centre in Malaysia described the pathological diagnosis of goitre and thyroid nodules following thyroidectomy. ${ }^{12}$ The burden of goitre in the adult Malaysian could not be extrapolated from these studies due to their unique approach and specific locations. Hence, the current 
study was designed to measure the prevalence of goitre in the Peninsular Malaysia as a whole and to determine the associated factors. In addition, after more than 25 years when the iodized salt is readily available, it would be of interest to look at the changes in the prevalence of goitre among the population.

\section{MATERIALS AND METHODS}

\section{Study Design and Population}

A cross-sectional study was conducted between 2014 and 2016.Malaysia is a country with 14 states and 3 federal territories; located in a peninsular (West Malaysia) and Borneo Island (East Malaysia), separated by the South China Sea. The majority of population resides in West Malaysia and comprises of three major ethnic groups; Malays (62\%), Chinese (21\%) and Indians (6\%). Most settlements were established along river banks and coastal areas. In term of socio-economy, $71 \%$ of Malaysia has been urbanized. ${ }^{13}$

We performed purposive sampling from five pre-assigned regions in Peninsular Malaysia based on their ethnic composition, geographical location and urbanization (socioeconomic status) to ensure samples are representative of Malaysian geosocio-economic characteristics. These regions were described in Table I.

Sample size was calculated using OpenEpi online sample size calculator available at http:// www.openepi.com/SampleSize/SSPropor.htm.

Based on the study done by Mafauzy et al., the prevalence of goitre in the State of Kelantan was $36.8 \%{ }^{9}$ Taking into account $50 \%$ response rate, the calculated sample size was 612 at $95 \%$ confidence interval and estimated design effect of 2.0.

\section{Data Collection}

All houses in a particular residential area in the pre-selected regions were included for sampling. Respondent from each household were selected by systematic random sampling using the KISH selection table adopted from the World Health Survey ${ }^{14}$. Selected respondents were invited to a community centre in their respective area for data collection.
Upon obtaining an informed consent, their sociodemographic profile was documented and a thorough medical history was taken. Physical examinations were done, paying attention to the thyroid and signs of hypo- or hyperthyroidism. The diagnoses of goitre were made by palpation done by the investigators (trained consultant physicians with at least 4 years of experience). Findings were corroborated by a repeat examination by another investigator; and subsequently a consensus on the grading of the thyroid lesion was reached. The classification of thyroid swellings was done based on the World Health Organization (WHO) recommendations. ${ }^{15}$ Normal neck examination where the thyroid gland was neither palpable nor visible was classified as Grade-0. Grade- 1 goitre was defined as a goitre that was palpable but not visible when the neck was in the normal position (i.e. the thyroid gland was not visibly enlarged). Nodules in a thyroid that was otherwise not enlarged fall into this category. Finally, Grade-2 goitre was a swelling in the neck that was clearly visible when the neck was in a normal position and was consistent with an enlarged thyroid gland when the neck was palpated. ${ }^{15}$

Fifteen millilitres of blood were withdrawn and transported to a central laboratory at the Universiti Kebangsaan Malaysia Medical Centre (UKMMC) for analysis. The hormonal assays and thyroid antibodies were performed by chemiluminescent microparticle immunoassays (CMIA) using the ARCHITECH 2000sr (Abbot) and IMMULITE $®$ i2000 (Siemens) systems, respectively. Overt and subclinical hypothyroidism were defined as TSH > $5.00 \mathrm{ulU} / \mathrm{mL}$; with free thyroxine $(\mathrm{fT} 4)<9.10 \mathrm{pmol} / \mathrm{L}$ and $\mathrm{fT} 4$ within the reference range $(9.10$ and $23.80 \mathrm{pmol} / \mathrm{L})$, respectively. Overt and subclinical hyperthyroidism was defined as TSH $<0.32 \mathrm{ulU} / \mathrm{mL}$; with $\mathrm{fT} 4$ above and within the reference range, respectively.

\section{Data Analysis}

The prevalence of thyroid dysfunction, thyroid antibodies and goitre were determined in the total sample [Total Population (TP), $n=2190]$. A subpopulation, known to have thyroid disease, goitre and/or on thyroid medication [Known Thyroid Disorder Population (KTDP), $n=136]$ were analysed to determine their thyroid function status, thyroid antibodies and the prevalence of goitre. Those 
Table I: Sample characteristics and prevalence of goitre in Peninsular Malaysia by region

\begin{tabular}{|c|c|c|c|c|c|c|c|}
\hline & Total & Region & & & & & $\mathrm{p}$-value \\
\hline & $2190(100.0)$ & $\begin{array}{c}\text { West } \\
379(100.0)\end{array}$ & $\begin{array}{c}\text { East } \\
498(100.0)\end{array}$ & $\begin{array}{c}\text { North } \\
323(100.0)\end{array}$ & $\begin{array}{c}\text { Central } \\
416(100.0)\end{array}$ & $\begin{array}{c}\text { South } \\
574(100.0)\end{array}$ & \\
\hline Location & & $\begin{array}{l}\text { Tanjung } \\
\text { Karang and } \\
\text { Kuala } \\
\text { Selangor }\end{array}$ & Kuantan & Bidor & Subang Jaya & Johor Bahru & \\
\hline Designation & & Rural & Urban & Rural & Urban & Urban & \\
\hline Location & & Coastal & Coastal & In-land & In-land & Coastal & \\
\hline \multicolumn{8}{|c|}{ Socio-demography } \\
\hline $\begin{array}{l}\text { Median age } \\
\text { (years) }\end{array}$ & $\begin{array}{l}52.0 \\
(39.0,61.0)\end{array}$ & $\begin{array}{l}55.0 \\
(41.0,65.0)\end{array}$ & $\begin{array}{l}41.0 \\
(24.0,53.0)\end{array}$ & $\begin{array}{l}54.0 \\
(44.0,65.0)\end{array}$ & $\begin{array}{l}56.5 \\
(49.0,62.0)\end{array}$ & $\begin{array}{l}53.0 \\
(39.8,61.0)\end{array}$ & $<0.001$ \\
\hline \multicolumn{8}{|l|}{ Gender } \\
\hline Male & $892(36.7)$ & $131(34.6)$ & 169 (33.9) & $139(43.0)$ & $169(40.6)$ & 206 (35.9) & 0.031 \\
\hline $\begin{array}{l}\text { Female } \\
\text { Ethnicity }\end{array}$ & $1536(63.3)$ & $248(65.4)$ & $329(66.1)$ & $184(57.0)$ & $247(59.4)$ & $368(64.1)$ & \\
\hline Malay & $1582(65.2)$ & $325(85.8)$ & $444(89.2)$ & $1(0.3)$ & $194(46.6)$ & $550(95.8)$ & $<0.001$ \\
\hline Chinese & $670(27.6)$ & $5(1.3)$ & $2.8(5.6)$ & $319(98.8)$ & $162(38.9)$ & $4(0.7)$ & \\
\hline Indian & $155(6.4)$ & $49(12.9)$ & $21(4.2)$ & $1(0.3)$ & $52(12.5)$ & $16(2.8)$ & \\
\hline $\begin{array}{l}\text { Others } \\
\text { lodine status }\end{array}$ & $21(0.9)$ & $0(0.0)$ & $5(1.0)$ & $2(0.6)$ & $8(1.9)$ & $4(0.7)$ & \\
\hline $\begin{array}{l}\text { Median } \\
\text { urinary iodine } \\
\text { (ug/L) (by } \\
\text { State) }\end{array}$ & & 126.0 & 76.5 & 77.8 & 131.0 & 118.0 & \\
\hline $\begin{array}{l}\text { Median } \\
\text { urinary } \\
\text { iodine (ug/L) } \\
\text { (by rural/ } \\
\text { urban)** }\end{array}$ & & $94(59,145)$ & $121(74,180)$ & $94(59,145)$ & $121(74,180)$ & $\begin{array}{l}121 \\
(74,180)\end{array}$ & \\
\hline \multicolumn{8}{|l|}{ Prevalence } \\
\hline $\begin{array}{l}\text { Total } \\
\text { population (TP) }\end{array}$ & $2190(100.0)$ & $379(100.0)$ & $498(100.0)$ & $323(100.0)$ & $416(100.0)$ & $574(100.0)$ & \\
\hline \multicolumn{8}{|l|}{ Goitre } \\
\hline Grade-0 & $1983(90.5)$ & $334(88.1)$ & $462(92.8)$ & $294(91.0)$ & $369(88.7)$ & $524(91.3)$ & 0.001 \\
\hline Grade-1 & $110(5.0)$ & $11(2.9)$ & $24(4.8)$ & 19 (5.9) & $23(5.5)$ & $33(5.7)$ & \\
\hline Grade-2 & $95(4.3)$ & $34(9.0)$ & $10(2.0)$ & $10(3.1)$ & $24(5.8)$ & $17(3.0)$ & \\
\hline $\begin{array}{l}\text { Total } \\
\text { Thyroidectomy }\end{array}$ & $2(0.1)$ & $0(0.0)$ & $2(0.4)$ & $0(0.0)$ & $0(0.0)$ & $0(0.0)$ & \\
\hline $\begin{array}{l}\text { Known } \\
\text { Thyroid } \\
\text { Disorder } \\
\text { Population } \\
\text { (KTDP) }\end{array}$ & $136(100.0)$ & $21(100.0)$ & $20(100.0)$ & $8(100.0)$ & $38(100.0)$ & $49(100.0)$ & \\
\hline \multicolumn{8}{|l|}{ Goitre } \\
\hline Grade-0 & 77 (56.6) & $12(66.7)$ & $12(60.0)$ & $3(37.5)$ & 22 (57.9) & $26(53.1)$ & 0.036 \\
\hline Grade-1 & $21(15.4)$ & $2(9.5)$ & $2(10.0)$ & $0(0.0)$ & $5(13.2)$ & $12(24.5)$ & \\
\hline Grade-2 & $36(26.5)$ & $5(13.8)$ & $4(20.0)$ & $5(62.5)$ & $11(28.9)$ & $11(22.4)$ & \\
\hline $\begin{array}{l}\text { Total } \\
\text { Thyroidectomy }\end{array}$ & $2(1.5)$ & $0(0.0)$ & $2(10.0)$ & $0(0.0)$ & $0(0.0)$ & $0(0.0)$ & \\
\hline $\begin{array}{l}\text { Disease-Free } \\
\text { Population } \\
\text { (DFP) }\end{array}$ & $2054(100.0)$ & $358(100.0)$ & $478(100.0)$ & $315(100.0)$ & $378(100.0)$ & $525(100.0)$ & \\
\hline \multicolumn{8}{|l|}{ Goitre } \\
\hline$\overline{\text { Grade-0 }} 0$ & $1906(92.8)$ & $320(89.4)$ & $450(94.1)$ & $291(92.4)$ & $347(91.8)$ & $498(94.9)$ & 0.001 \\
\hline Grade-1 & $89(4.3)$ & $9(2.5)$ & $22(4.6)$ & $19(6.0)$ & $18(4.8)$ & $21(4.0)$ & \\
\hline Grade-2 & $59(2.9)$ & $29(8.1)$ & $6(1.3)$ & $5(1.6)$ & $13(3.4)$ & $6(1.1)$ & \\
\hline
\end{tabular}

* WM Wan Nazaimoon et al, $2010^{22}$

** Rusidah Selamat et al, $2010^{23}$ 
without known thyroid disease, goitre and/or on thyroid medication were termed as Disease-Free Population (DFP), $\mathrm{n}=2054$. Form this sub-population the prevalence of newly diagnosed goitre was determined (Figure 1).

Statistical analysis was descriptive and exploratory. For the total population and sub-populations, all continuous variables were tested for normality using graphics in addition to Kolmogorov-Smirnov test. Non-normally distributed data was presented as median $\left(25^{\text {th }}, 75^{\text {th }}\right.$ centile), except for some cases where $95^{\text {th }}$ centile was used. Bivariate analyses were done using t-test and Man Whitney-U test where appropriate. Chi-square was used for comparison between two or more categorical variables. Finally, binary logistic regression were used to determine predictors for goitre.

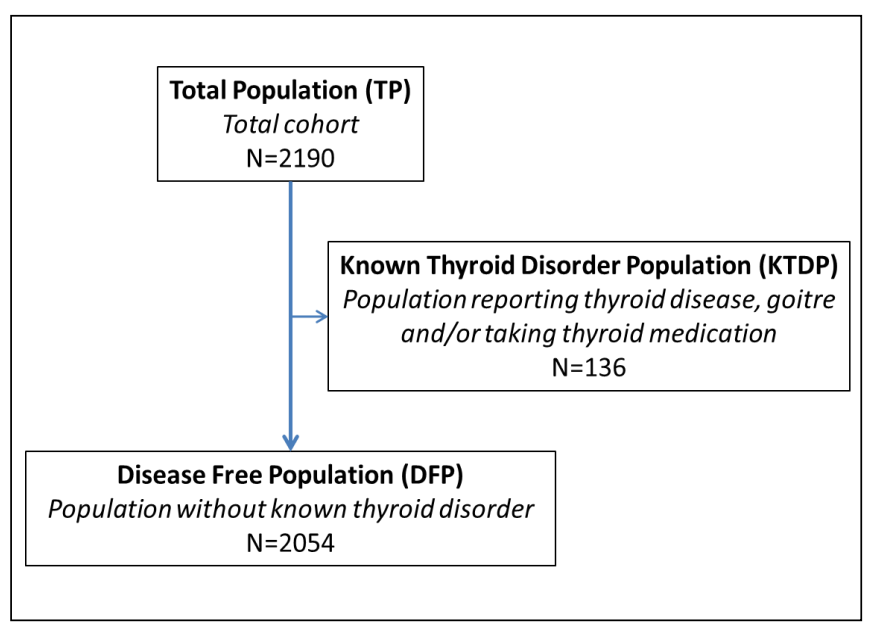

Figure 1: Total Population and its sub-populations

\section{Ethical Consideration}

This study was approved by the Medical Research and Ethics Committee (MREC), Universiti Kebangsaan Malaysia (UKM), Kuala Lumpur (Research Code: FF2014-286) and Medical Research Ethics Committee, Ministry of Health (Research Code: NMRR-13-160518629).

\section{RESULTS}

\section{Population characteristics}

A total of 2259 respondents were enrolled in this study. Sixty-nine respondents were excluded because of missing data. A total of 2190 respondents were analysed for the prevalence of goitre. However, 2182 and 2181 respondents were analysed for thyroid antibodies and thyroid function, respectively (Figure 2).
Our sample was similar to the Malaysian population demography in terms of ethnicity. However, our sample was older and majority of respondents were female (Table II). This was because of the timing of sampling; it was done during working hours and majority of female are housewives and younger age group are in the workforce. Almost similar to the rate of urbanization in Malaysia, $67.9 \%$ of respondents were from urban areas. The sociodemographic details of respondents from each sampling region are described in Table I.

Table II: Comparison between sample cohort and Malaysian population

\begin{tabular}{lcc}
\hline Characteristics & \multicolumn{2}{c}{ \% of Subjects } \\
\cline { 2 - 3 } & $\begin{array}{c}\text { Study } \\
\text { Population } \\
(\mathrm{N}=2,190)\end{array}$ & $\begin{array}{c}\text { Malaysian } \\
\text { Population* } \\
(\mathrm{N}=30,995,700)\end{array}$ \\
\hline $\begin{array}{l}\text { Age } \\
\text { distribution }\end{array}$ & 9.8 & 19.4 \\
$18-24$ & 9.9 & 18.7 \\
$25-34$ & 13.7 & 13.0 \\
$35-44$ & 23.5 & 10.6 \\
$45-54$ & 26.6 & 7.4 \\
$55-64$ & 12.9 & 3.9 \\
$65-74$ & 3.7 & 2.0 \\
$>74$ & 52.0 & 27.8 \\
Median age & $58.1: 100$ & $106.6: 100$ \\
Male: Female & & \\
Ratio & & \\
Ethnicity & 69.1 & 61.8 \\
Malay & 23.7 & 21.4 \\
Chinese & 6.3 & 6.4 \\
Indian & 0.9 & 0.9 \\
Others & 0.0 & 9.6 \\
Non-Malaysian & & \\
\hline Current Populan & &
\end{tabular}

${ }^{*}$ Current Population Estimate 2015, Department of Statistics Malaysia

\section{Goitre}

The prevalence of goitre in the TP was $9.3 \%(5.0 \%$ was Grade-1 and 4.3\% Grade-2 goitre). In the KTDP, $15.4 \%$ and $26.5 \%$ had Grade-1 and Grade-2 goitre, respectively. Two respondents had undergone total thyroidectomy. Among the DFP, the prevalence of goitre was $7.2 \%$, and $4.3 \%$ and $2.9 \%$ were Grade- 1 and Grade-2, respectively (Table I).

The proportion of newly diagnosed goitre was higher compared to those with known thyroid disorders (Grade-1: 81\% versus 20\%; and Grade-2: 62\% versus $38 \%)$. Almost two third of the DFP was not aware that they have visible and palpable goitre. The prevalence of newly diagnosed Grade-1 goitre is higher than Grade-2 goitre (Figure 3). 
In term of geographical location, respondents from the west coast of the peninsular (sampled from a rural and coastal area) recorded the highest prevalence of goitre (11.9\%; where $2.9 \%$ and $9.0 \%$ were Grade-1 and Grade-2, respectively) followed by the central region which was sampled from an urban and in-land population (11.3\%); $5.5 \%$ was Grade- 1 and $5.8 \%$ was Grade-2 goitre.

The third highest goitre prevalence was recorded in the northern region $(9.0 \%)$ (Table I). In relation to this observation, the west coast and central region are known as iodine sufficient areas, while the Northern region which was located in rural and inland area had been reported to have lower iodine status in two previous studies. ${ }^{16,17}$ The population from the east coast (coastal area) had significantly lower prevalence of goitre $(6.8 \%, p<0.001)$ (Table I).

Goitre was significantly more prevalent among the younger population. The prevalence of goitre was higher in those aged less than 45 years old $(12 \%$ versus $8 \% ; p=0.008$ ). Female had higher prevalence of goitre compared to male in the TP (female: $12.2 \%$ versus male: $4.6 \% ; \mathrm{p}<0.001$ ) and the DFP (female: 9.3\% versus male: $2.9 \%$; $<<0.001$ ) (Table III). Indian ethnicity had the highest prevalence of goitre than that of other races among the TP $119.4 \%$ for Indian, Malay $8.9 \%$, Chinese $8.3 \%$ and others $10.6 \%$; $p<$ $0.001)$ and among the DFP $(\mathrm{p}<0.001)$ (Table III).

Table III: Total Prevalence of goitre and thyroid nodule; and its distribution according to gender, ethnicity; and association with thyroid antibodies

\begin{tabular}{|c|c|c|c|c|c|c|c|c|c|}
\hline & \multirow[b]{2}{*}{ N (\%) } & \multicolumn{2}{|c|}{ Gender } & \multirow[b]{2}{*}{ p-value } & \multicolumn{4}{|c|}{ Ethnicity } & \multirow[b]{2}{*}{ p-value } \\
\hline & & Male & Female & & Malay & Chinese & Indian & Others & \\
\hline $\begin{array}{l}\text { Total } \\
\text { Population } \\
\text { (TP) }\end{array}$ & $\begin{array}{l}2190 \\
(100.0)\end{array}$ & $\begin{array}{l}814 \\
(100.0)\end{array}$ & $\begin{array}{l}1376 \\
(100.0)\end{array}$ & & $\begin{array}{l}1514 \\
(100.0)\end{array}$ & $\begin{array}{l}518 \\
(100.0)\end{array}$ & $\begin{array}{l}139 \\
(100.0)\end{array}$ & $\begin{array}{l}19 \\
(100.0)\end{array}$ & \\
\hline \multicolumn{10}{|l|}{ Goitre } \\
\hline Grade-0 & $\begin{array}{l}1983 \\
(90.5)\end{array}$ & $\begin{array}{l}777 \\
(95.5)\end{array}$ & $\begin{array}{l}1206 \\
(87.6)\end{array}$ & $\hat{0}_{0.001^{* a}}$ & $\begin{array}{l}1379 \\
(91.1)\end{array}$ & $\begin{array}{l}475 \\
(91.7)\end{array}$ & $\begin{array}{l}112 \\
(80.6)\end{array}$ & $\begin{array}{l}17 \\
(89.5)\end{array}$ & $<0.001^{* a}$ \\
\hline Grade-1 & $110(5.0)$ & $\begin{array}{l}20 \\
(2.5)\end{array}$ & $\begin{array}{l}90 \\
(6.5)\end{array}$ & & $\begin{array}{l}76 \\
(5.0)\end{array}$ & $\begin{array}{l}27 \\
(5.2)\end{array}$ & $\begin{array}{l}6 \\
(4.3)\end{array}$ & $\begin{array}{l}1 \\
(5.3)\end{array}$ & \\
\hline Grade-2 & $\begin{array}{l}95 \\
(4.3)\end{array}$ & $\begin{array}{l}17 \\
(2.1)\end{array}$ & $\begin{array}{l}78 \\
(5.7)\end{array}$ & & $\begin{array}{l}57 \\
(3.8)\end{array}$ & $\begin{array}{l}16 \\
(3.1)\end{array}$ & $21(15.1)$ & $\begin{array}{l}1 \\
(5.3)\end{array}$ & \\
\hline $\begin{array}{l}\text { Total } \\
\text { thyroidectomy }\end{array}$ & $\begin{array}{l}2 \\
(0.1)\end{array}$ & $\begin{array}{l}0 \\
(0.0)\end{array}$ & $\begin{array}{l}2 \\
(0.1)\end{array}$ & & $\begin{array}{l}2 \\
(0.1)\end{array}$ & $\begin{array}{l}0 \\
(0.0)\end{array}$ & $\begin{array}{l}0 \\
(0.0)\end{array}$ & $\begin{array}{l}0 \\
(0.0)\end{array}$ & \\
\hline $\begin{array}{l}\text { Known } \\
\text { Thyroid } \\
\text { Disorder } \\
\text { Population } \\
\text { (KTDP) }\end{array}$ & $\begin{array}{l}136 \\
(100.0)\end{array}$ & $\begin{array}{l}21 \\
(100.0)\end{array}$ & $\begin{array}{l}115 \\
(100.0)\end{array}$ & & $\begin{array}{l}91 \\
(100.0)\end{array}$ & $\begin{array}{l}31 \\
(100.0)\end{array}$ & $\begin{array}{l}14 \\
(100.0)\end{array}$ & & \\
\hline \multicolumn{10}{|l|}{ Goitre } \\
\hline Grade-0 & $\begin{array}{l}77 \\
(56.6)\end{array}$ & $\begin{array}{l}15 \\
(71.4)\end{array}$ & $\begin{array}{l}62 \\
(53.9)\end{array}$ & $0.358^{\mathrm{a}}$ & $\begin{array}{l}50 \\
(54.9)\end{array}$ & $20(64.5)$ & $\begin{array}{l}7 \\
(50.0)\end{array}$ & & $0.544^{\mathrm{a}}$ \\
\hline Grade-1 & $\begin{array}{l}21 \\
(15.4)\end{array}$ & $\begin{array}{l}1 \\
(4.8)\end{array}$ & $\begin{array}{l}20 \\
(17.4)\end{array}$ & & $\begin{array}{l}17 \\
(18.7)\end{array}$ & $\begin{array}{l}3 \\
(9.7)\end{array}$ & $\begin{array}{l}1 \\
(7.1)\end{array}$ & & \\
\hline Grade-2 & $\begin{array}{l}36 \\
(26.5)\end{array}$ & $\begin{array}{l}5 \\
(23.8)\end{array}$ & $\begin{array}{l}31 \\
(27.0)\end{array}$ & & $\begin{array}{l}22 \\
(24.2)\end{array}$ & $\begin{array}{l}8 \\
(25.8)\end{array}$ & $\begin{array}{l}6 \\
(42.9)\end{array}$ & & \\
\hline $\begin{array}{l}\text { Total } \\
\text { thyroidectomy }\end{array}$ & $\begin{array}{l}2 \\
(1.5)\end{array}$ & $\begin{array}{l}0 \\
(0.0)\end{array}$ & $\begin{array}{l}2 \\
(1.7)\end{array}$ & & $\begin{array}{l}2 \\
(2.2)\end{array}$ & $\begin{array}{l}0 \\
(0.0)\end{array}$ & $\begin{array}{l}0 \\
(0.0)\end{array}$ & & \\
\hline $\begin{array}{l}\text { Disease-Free } \\
\text { Population } \\
\text { (DFP) }\end{array}$ & $\begin{array}{l}2054 \\
(100.0)\end{array}$ & $\begin{array}{l}793 \\
(100.0)\end{array}$ & $\begin{array}{l}1261 \\
(100.0)\end{array}$ & & $\begin{array}{l}1423 \\
(100.0)\end{array}$ & $\begin{array}{l}487 \\
(100.0)\end{array}$ & $\begin{array}{l}125 \\
(100.0)\end{array}$ & $\begin{array}{l}19 \\
(100.0)\end{array}$ & \\
\hline \multicolumn{10}{|l|}{ Goitre } \\
\hline Grade-0 & $\begin{array}{l}1906 \\
(92.8)\end{array}$ & $\begin{array}{l}762 \\
(96.1)\end{array}$ & $\begin{array}{l}1144 \\
(90.7)\end{array}$ & $<0.001^{* a}$ & $\begin{array}{l}1329 \\
(93.4)\end{array}$ & $\begin{array}{l}455 \\
(93.4)\end{array}$ & $\begin{array}{l}105 \\
(84.0)\end{array}$ & $\begin{array}{l}17 \\
(89.5)\end{array}$ & $<0.001^{* a}$ \\
\hline Grade-1 & $\begin{array}{l}89 \\
(4.3)\end{array}$ & $\begin{array}{l}19 \\
(2.4)\end{array}$ & $\begin{array}{l}70 \\
(5.6)\end{array}$ & & $\begin{array}{l}59 \\
(4.1)\end{array}$ & $\begin{array}{l}24 \\
(4.9)\end{array}$ & $\begin{array}{l}5 \\
(4.0)\end{array}$ & $\begin{array}{l}1 \\
(5.3)\end{array}$ & \\
\hline Grade-2 & $\begin{array}{l}59 \\
(2.9)\end{array}$ & $\begin{array}{l}12 \\
(1.5)\end{array}$ & $\begin{array}{l}47 \\
(3.7)\end{array}$ & & $\begin{array}{l}35 \\
(2.5)\end{array}$ & $\begin{array}{l}8 \\
(1.6)\end{array}$ & $\begin{array}{l}15 \\
(12.0)\end{array}$ & $\begin{array}{l}1 \\
(5.3)\end{array}$ & \\
\hline
\end{tabular}




\begin{tabular}{|c|c|c|c|c|c|c|}
\hline & \multicolumn{6}{|c|}{ Thyroid antibodies } \\
\hline & \multicolumn{3}{|c|}{ Anti-TPO } & \multicolumn{3}{|c|}{ Anti-TG } \\
\hline & Negative & Positive & p-value & Negative & Positive & p-value \\
\hline $\begin{array}{l}\text { Total } \\
\text { Population } \\
\text { (TP) }\end{array}$ & $1916(87.8)$ & $266(12.2)$ & & 1918 (87.9) & $264(12.1)$ & \\
\hline \multicolumn{7}{|l|}{ Goitre } \\
\hline Grade- 0 & $1761(89.2)$ & $214(10.8)$ & $<0.001^{* a}$ & $1764(89.3)$ & $211(10.7)$ & $<0.001^{* a}$ \\
\hline Grade-1 & $90(81.8)$ & $20(18.2)$ & & $88(10.0)$ & $22(20.0)$ & \\
\hline Grade-2 & $65(68.4)$ & $30(31.6)$ & & $65(68.4)$ & $30(31.6)$ & \\
\hline $\begin{array}{l}\text { Total } \\
\text { thyroidectomy }\end{array}$ & $0(0.0)$ & $2(0.1)$ & & $1(50.0)$ & $1(50.0)$ & \\
\hline $\begin{array}{l}\text { Known } \\
\text { Thyroid } \\
\text { Disorder } \\
\text { Population } \\
\text { (KTDP) }\end{array}$ & $83(61.0)$ & $53(39.0)$ & & $95(69.9)$ & $41(30.1)$ & \\
\hline \multicolumn{7}{|l|}{ Goitre } \\
\hline Grade- 0 & $52(67.5)$ & $25(32.5)$ & $0.022^{* a}$ & $60(77.9)$ & $17(22.1)$ & $0.005^{* a}$ \\
\hline Grade-1 & $15(71.4)$ & $6(28.6)$ & & $17(81.0)$ & $4(19.0)$ & \\
\hline Grade-2 & $16(44.4)$ & $20(55.6)$ & & $17(47.2)$ & $19(52.8)$ & \\
\hline $\begin{array}{l}\text { Total } \\
\text { thyroidectomy }\end{array}$ & $0(0.0)$ & $2(100.0)$ & & $1(50.0)$ & $1(50.0)$ & \\
\hline $\begin{array}{l}\text { Disease-Free } \\
\text { Population } \\
\text { (DFP) }\end{array}$ & $1834(89.6)$ & $213(10.4)$ & & $1824(89.1)$ & $223(10.9)$ & \\
\hline \multicolumn{7}{|l|}{ Goitre } \\
\hline Grade-0 & $1709(90.0)$ & $190(10.0)$ & 0.094 & 1704 (89.7) & $195(10.3)$ & $0.005^{*}$ \\
\hline Grade-1 & $76(85.4)$ & $13(14.6)$ & & $72(80.9)$ & $17(19.1)$ & \\
\hline Grade-2 & $49(83.1)$ & $10(16.9)$ & & $48(81.4)$ & $223(10.9)$ & \\
\hline
\end{tabular}

*Significant association

${ }^{a}$ Chi-Square $\left(X^{2}\right)$ Test

In the TP, the prevalence of positive antithyroperoxidase (anti-TPO) among those with Grade1 and Grade-2 goitre were $18.2 \%$ and $31.6 \%$, respectively. Approximately $32 \%$ of respondents with Grade- 2 goitre and $20.0 \%$ of respondents with Grade -1 goitre had positive anti-thyroglobulin (anti-TG). Among respondents in the KTDP with goitre, the prevalence of positive anti-TPO and anti-TG was as high as $55.6 \%$. In general, those with larger goitre tend to have higher frequency of positive thyroid antibodies. However in the DFP, $19.1 \%$ of those with Grade-1 goitre and $10.9 \%$ with Grade- 2 goitre had positive anti-TG $(p=0.005)$. In addition, respondents with larger goitre in the DFP did show a tendency to have higher frequency of positive anti-TPO, however the differences were not statistically significant (Table III).

\section{Determinants of goitre}

Those with younger age group was $12 \%$ more likely to have goitre (Crude OR $=0.98 ; 95 \% \mathrm{Cl}$ 0.97-0.99). Females were 2.9 times higher risk to have goitre than males. Being Indian was 2.4 times more risk for goitre compared to other ethnic groups. The effect of socioeconomic status and geographical location on goitre was not evident. Those who were underweight and had normal body mass index (BMI) were at higher risk of goitre (crude OR of 2.17 and 1.68 , respectively). Finally, those with positive antiTPO and anti-TG were 2.8 and 2.9 times higher risk of developing goitre compared to those with negative antibodies $(\mathrm{p}<0.001)$ (Table IV). 
Table IV: Odd ratio of variables that predicts the presence of goitre

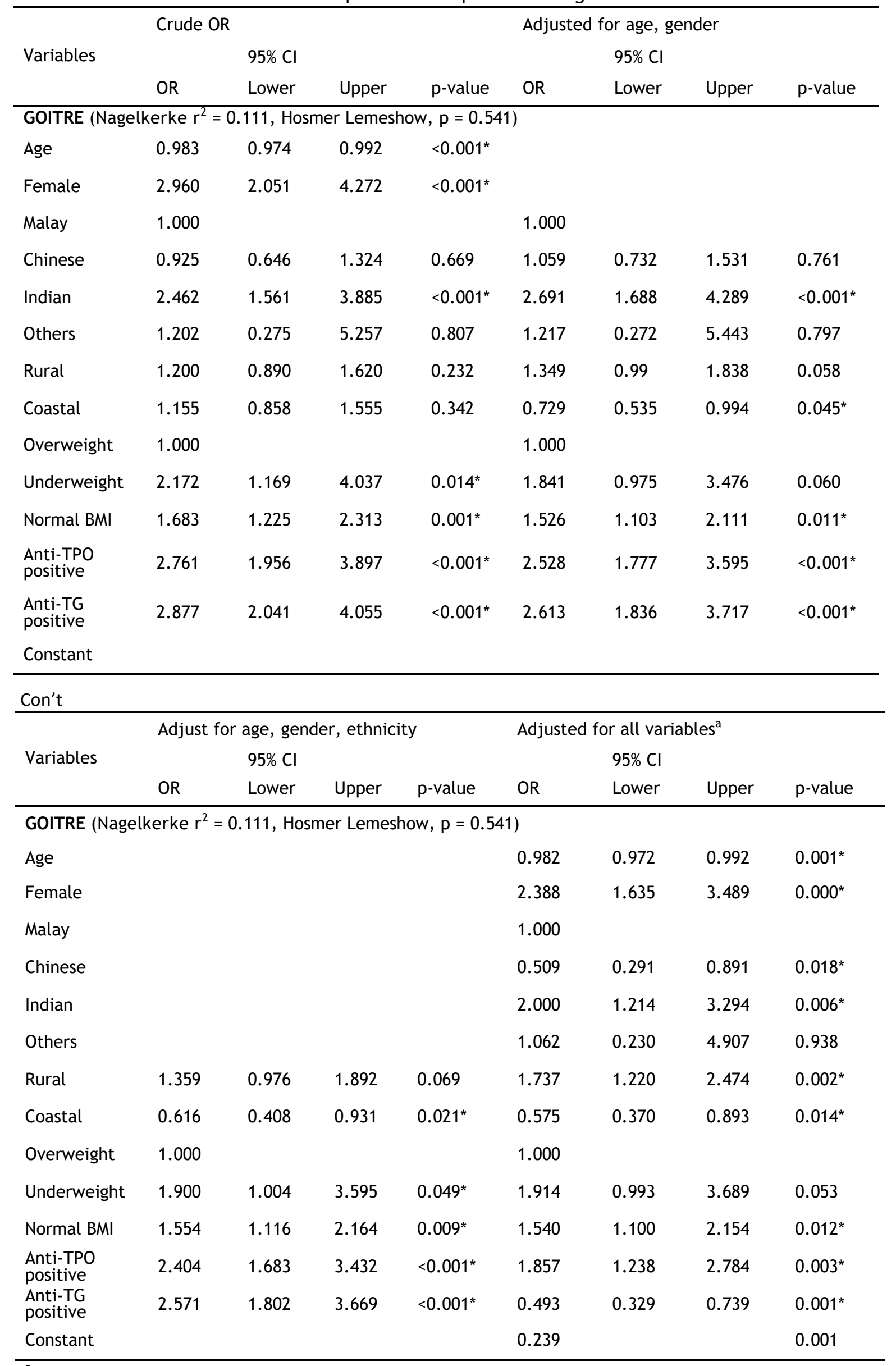

${ }^{a}$ Variables entered: age, female, ethnicity, socioeconomy (rural vs urban), geographical location (coastal vs inland), body mass index (BMI), anti-TPO positive, anti-TG positive

*statistically significant 


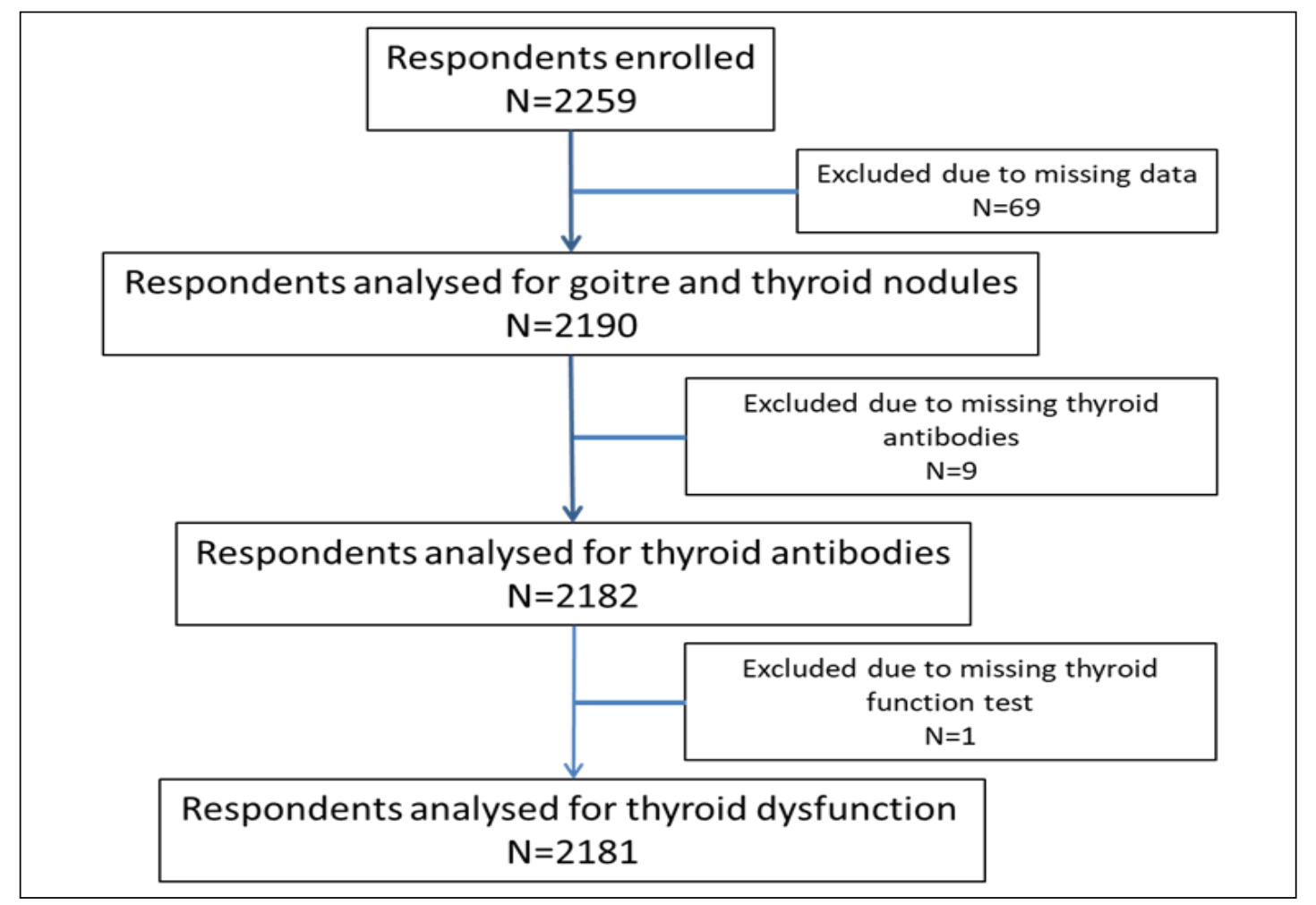

Figure 2: Respondents enrolled

When adjusted for age and gender, we found that being Indian maintained the increased risk of having goitre (adjusted OR=2.7,95\% Cl=1.69-4.29); while living in coastal areas reduced the risk of having goitre by $27 \%$. Having lower BMI remained a significant risk factor for goitre. Anti-TPO and antiTG positive remained important predictors for having goitre with the adjusted OR of $2.5(95 \% \mathrm{Cl}$ $1.78-3.60)$ and $2.6(95 \% \mathrm{Cl} 1.84-3.72)$, respectively (Table IV).

When adjusted for all the variables, we found that younger age, female gender and ethnicity were significant determinants for goitre. Chinese ethnicity was at lower risk for developing goitre, however Indian ethnicity had twice the risk of having goitre compared to the Malay population. Those living in the rural were 1.7 times at higher risk for developing goitre compared from urban area. On the other hand, those living in the coastal area were at lower risk for goitre $(\mathrm{OR}=0.58 ; 95 \% \mathrm{Cl}$ $0.37-0.89)$.

Those who had normal BMI have higher risk of goitre compared from overweight population. Thyroid antibodies remained important predictors of goitre. However, contrary to positive anti-TPO, those with positive anti-TG were lower risk of having goitre compared from those with negative thyroid antibodies.

\section{DISCUSSION}

\section{Prevalence of goitre}

This study investigated the burden of goitre among adult population in Peninsular Malaysia. The overall prevalence of Grade-1 and Grade-2 goitre was $5.0 \%$ and $4.3 \%$, respectively. The prevalence of goitre of $9.3 \%$ in the current study was comparable with other studies where the goitre prevalence was between $7.0 \%$ and $15.5 \% .^{1-6}$ In contrast in China, where excessive exposure to iodine has been reported, the prevalence of thyroid nodules (classified as Grade-1 goitre in our study) were between $22.7 \%$ and $40.1 \% .^{5,18}$

Comparing with the previous studies in Malaysia, the prevalence of goitre in this study was found to be lower, even in places of similar geographical locations (i.e. coastal and in-land areas). Mafauzy et al. reported the overall goitre (i.e. Grade-1, Grade-2 and Grade-3) prevalence of $36.8 \%$, whereas our prevalence (i.e. Grade- 1 and Grade- 2 goitre) was $9.3 \%$. In coastal areas of Kelantan, Mafauzy et al. reported that the prevalence of goitre to be $23.0 \%$; much higher in comparison to our highest goitre prevalence $(11.9 \%)$ in the coastal areas of Kuala Selangor and Tanjung Karang. Consistently, in inland areas of Kelantan, the goitre prevalence was $44.9 \%$; while our prevalence was only $9.0 \%$ in the in- 


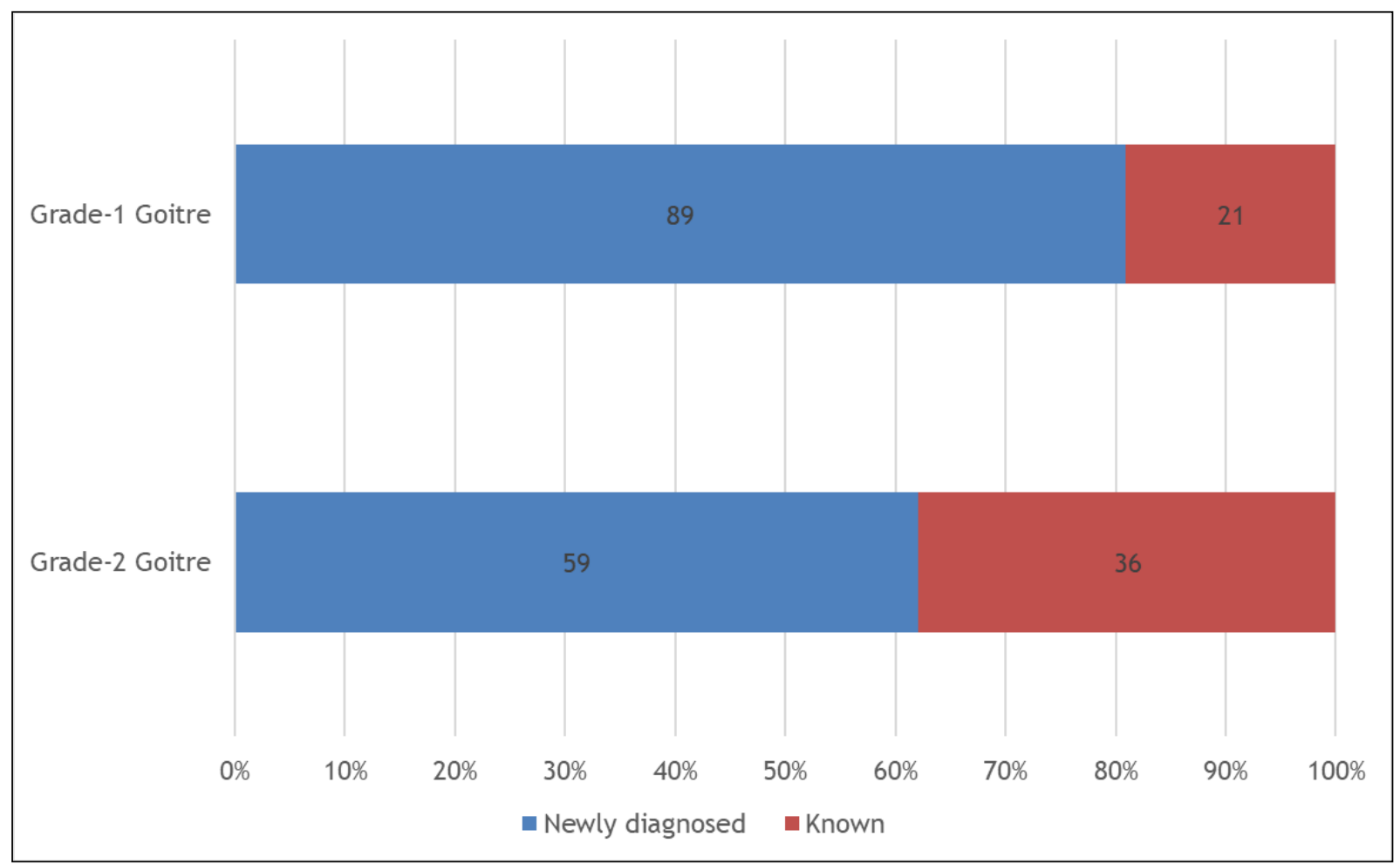

Figure 3: The proportion of undiagnosed goitre in the Malaysian adult population

land area of Bidor. ${ }^{9}$ Although these numbers were derived from different set of cohorts, we postulate that there was true reduction in the prevalence of goitre as iodized salt were made available throughout the country over the past 25 years.

Among those diagnosed with goitre, $81 \%$ of Grade-1 and $62 \%$ of Grade-2 goitre were new findings. This brings the concern that large proportion of the population ignored obvious abnormality in the neck. It would be important for future studies to look at the reasons behind such health seeking behaviour. Among the reasons that could led to the neglected neck swellings in the population is lack of awareness. Secondly, health advocates should also look into whether reduced accessibility to healthcare services has contributed to undiagnosed goitre.

\section{The aetiologies of goitre in our population}

The prevalence of goitre was higher in females compared to males in both the TP and DFP groups. Higher prevalence of goitre was seen in the younger age group. This observation was consistent with other epidemiological studies abroad. ${ }^{19,20}$ We postulate that the goitre in the younger age group is likely to be autoimmune in origin. Further strengthening that notion, the presence of goitre was associated with positive anti-TPO and anti-TG antibodies in the TP $(p<0.001)$ with similar trend among the KTDP and the DFP who had goitre. Although, this observation supports the possibility of autoimmune thyroid disorders, other aetiologies such as malignancy which is not uncommon in the younger age group could not be ruled out. Therefore, further research on this matter is warranted.

\section{Goitre, ethnicity and iodine availability}

Indians had a higher prevalence of goitre especially Grade-2. However, the trend was lost when analysis was made among the KTDP. The high prevalence may be attributed to small number of Indian samples represented in this study. Secondly, most of the Indian population sampled for this study came from two areas (West Coast and Central region); therefore, geographical location may be an important confounding factor to this observation.

In the TP, the highest prevalence of goitre was among the West (rural and coastal) and Central (urban) regions followed by the Northern region (rural and in-land). The goitre in the West and Central regions are associated with high titres of anti -TPO and anti-TG. On the other hand, the Northern region had significantly higher prevalence of goitre with lower titre of thyroid antibodies (Figure 4). This observation was consistent with many previous reports which elucidated that iodine availability in a 
particular geographical location was an important factor for development of goitre. Although, iodine level was not measured in the current study, coastal and urban areas, in general, are exposed to more iodine than in-land and rural areas. This fact was supported by the prior local studies. ${ }^{9,16,17}$ Other studies in the past also demonstrated the importance of iodine availability in the epidemiology of goitre. ${ }^{5,19,20}$

\section{Determinants for goitre}

The presence of goitre was determined by a number of factors. Age and gender remained significant factors that predict the presence of goitre in both univariate and multivariate analysis. The risk of Indians getting goitre was at least twice than that of Malay ethnicity. This observation was consistent even when adjusted for all variables indicating that ethnicity may play a real role in determining the prevalence of goitre. However, whether the reason is purely genetic or environmental is still unanswered as we have discussed earlier.

When adjusted for age, gender and ethnicity, those living in coastal areas were found to have a lower risk of developing goitre compared from those residing in in-land area. This may be related to the presence of iodine deficiency in in-land areas. When all variables were considered, we also found that those in rural area were 1.7 times more risk of developing goitre compared to those in urban areas. Based on low iodine levels in rural areas reported in previous study, ${ }^{17}$ this observation also strengthened the notion that iodine deficiency may be an important factor in determining the presence of goitre in the Malaysian adult population. However, it must be kept in mind that the influence of iodine exposure on the study population remains a postulation until a proper study on urinary iodine excretion is undertaken.

In our cohort, those with normal BMI was at risk of goitre compared to those who are overweight. We hypothesize that BMI was the effect on thyroid dysfunction rather than true determinant of goitre. This observation may elucidate that the presences of goitre in our study population possibly be associated with hyperthyroidism in which one of the symptoms is weight loss.

Those with positive anti-TPO was almost twice at risk of having goitre compared to those with negative antibodies. Positive anti-TG was associated with 2.5 times risk of goitre. Therefore, we can speculate that the presence of thyroid antibodies are strong risk factors for goitre, although, a

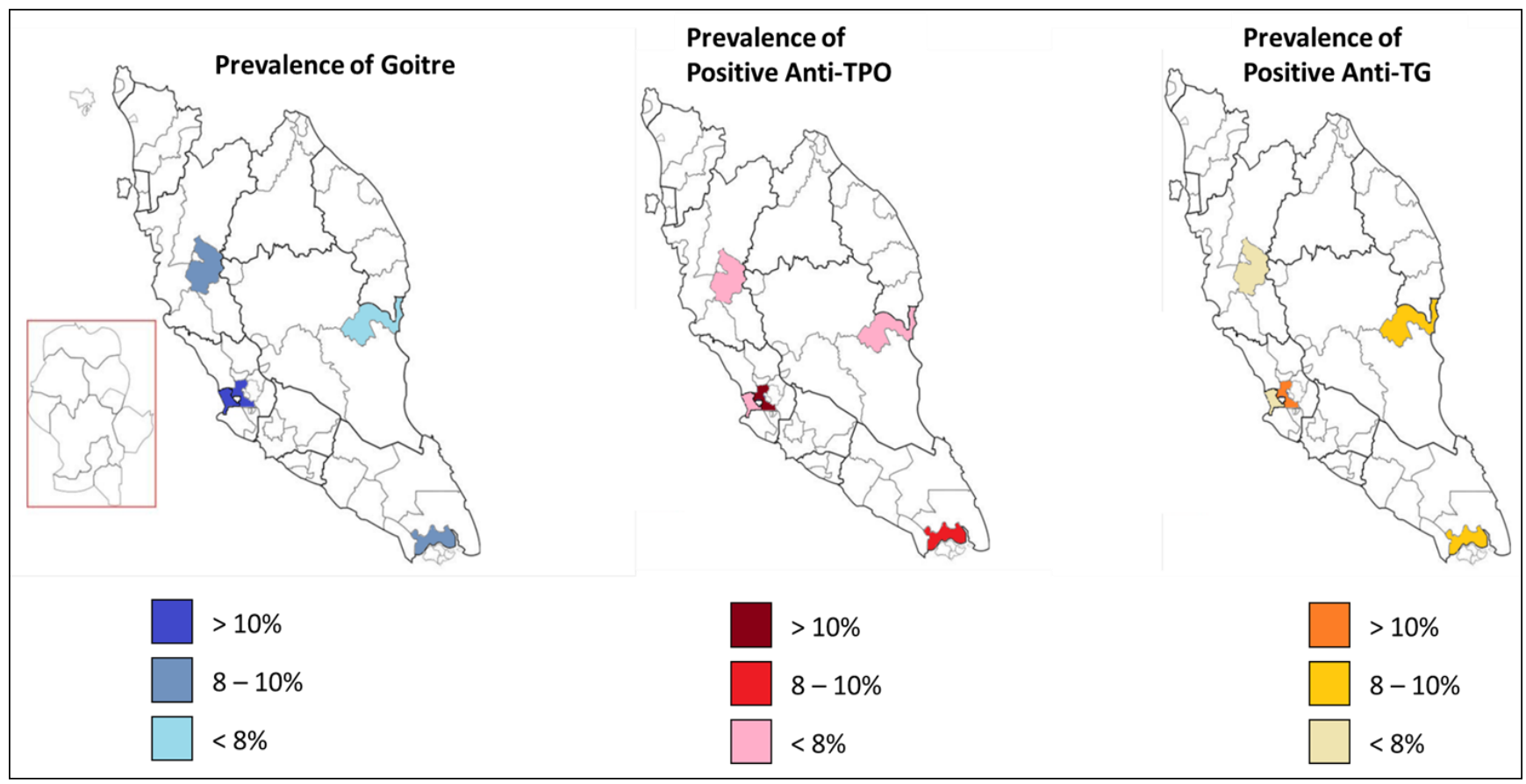

Figure 4: The prevalence of goitre, anti-TPO and anti-TG according to geographical location, note that; In areas with high prevalence of goitre located in urban and coastal region the frequency of anti-TPO and anti-TG is moderate to high; In area of high prevalence of goitre located in in-land area, the frequency of positive anti-TPO and anti-TG is the lowest. 
negative relationship between anti-TG and goitre was seen when all variables were entered into the multivariate equation. A plausible explanation for the negative relationship is that, it is may be the case that goitre in our population are mostly associated with anti-TPO; which is common in conditions such Hashimoto's thyroiditis. In addition to that, anti-TG in conditions such as Graves disease may become negative after therapy. Graves disease and Hashimoto's thyroiditis are two common thyroid conditions seen in clinical practice.

Although, the current epidemiological study gave us an idea of the level of importance of certain predictors for goitre, these factors only predicts small percentage of the outcome. Other factors, such as family history and iodine status, which were not studied may contribute to better prediction models.

\section{Limitations}

The limitations of this study include that the technique use for detection of goitre was by palpation. Inevitably, we would miss thyroid nodules which are subclinical and can only be detected by ultrasound. Secondly, although the findings elucidated the relationship between goitre and iodine status based on geographical locations, the iodine levels were not measured but inferred from previous studies.

\section{CONCLUSIONS AND CLINICAL IMPLICATION}

The prevalence of goitre in this population was $9.3 \%$. Higher prevalence of goitre was observed in females, the young age group and Indians. The higher prevalence of goitre in rural and in-land areas may be indicative of iodine insufficiency. Female was a strong predictor for goitre. Indian ethnicity was a risk factor for goitre and anti-TPO. Living in rural areas predispose a person for goitre. Goitre of autoimmune aetiology is more likely among those who reside in coastal and urban areas. Pockets of areas where iodine deficiency is prevalent, especially in rural areas need to be investigated and appropriate intervention should be instituted. The policy makers should consider goitre as a public health concern and plan for appropriate strategy for managing the newly diagnosed goitre. Moreover, this study has laid-out the current burden of goitre among adult population in Peninsular Malaysia, but detailed aetiology of these findings requires further research.

\section{ACKNOWLEDGMENT}

The Malaysian Endocrine Disorders (MyENDO) Study Group: Kuck Meng CHONG (Klinik Chong), Hanita OTHMAN (UKMMC), Kwa Siew KIM (International Medical University-IMU), G R Letchuman RAMANATHAN (Hospital Taiping), Huai Heng LOH (Universiti Malaysia Sarawak-UNIMAS), Luqman IBRAHIM (University of Malaya-UM), Norhaliza MOHD ALI (Hospital Sultanah Aminah-HSA), CP OOI (Universiti Putra Malaysia-UPM), Subashini SELVARAJOO (Hospital Kuala Lumpur), Wan Juani WAN SEMAN (Hospital Putrajaya), Yusniza YUSOFF (Hospital Sungai Buloh) and Zanariah HUSSEIN (Hospital Putrajaya).

The study was funded by the Malaysian Endocrine and Metabolic Society (MEMS).

\section{REFERENCES}

1. Tunbridge WM., Evered D., Hall R, et al. The Spectrum of thyroid disease in a community: The Wickham Survey. Clin Endocrinol (Oxf). 1977;7:481-491.

2. Vanderpump MPJ, Tunbridge WM., Evanst JG, et al. The incidence of thyroid disorders in the communitya: a twenty-year follow-up of the Whickham Survey. Clin Endocrinol (Oxf). 1995;43:55-68.

3. Kasagi K, Takahashi N, Inoue G, Honda T, Kawachi $Y$, Izumi $Y$. Thyroid function in Japanese adults as assessed by a general health checkup system in relation with thyroid-related antibodies and other clinical parameters. Thyroid. 2009;19(9):937-944. doi:10.1089/ thy.2009.0205

4. Usha Menon V, Sundaram K, Unnikrishnan A, Jayakumar R, Nair V, Kumar H. High prevalence of undetected thyroid disorders in an iodine sufficient adult south Indian population. $J$ Indian Med Assoc. 2009;107:72-77.

5. Zhao W, Han C, Shi X, et al. Prevalence of goiter and thyroid nodules before and after implementation of the Universal Salt lodization program in mainland China from 1985 to 2014: A systematic review and meta-analysis. PLoS One. 2014;9(10). doi:10.1371/journal.pone.0109549

6. Yu X, Fan C, Shan Z, et al. A five-year follow-up 
study of goiter and thyroid nodules in three regions with different iodine intakes in China. $J$ Endocrinol invest. 2008;31:243-250. doi:10.1007/BF03345597

7. Brahmbhatt S, Brahmbhatt R, Boyages S. Impact of protein energy malnutrition on thyroid size in an iodine deficient population of Gujarat (India): Is it an aetiological factor for goiter? Eur J Endocrinol. 2001;145(1):1117. doi:10.1530/eje.0.1450011

8. Chen PCY. The prevalence of endemic goitre among penans of the baram. 1988;(2):159-161.

9. Mafauzy M, Musalmah M. The Prevalence of Endemic Goitre in Kelantan , Malaysia. Med J Malaysia. 1993;48(1):64-70.

10. Foo LC, Zainab T, Letchuman GR, et al. Endemic goiter in the Lemanak and Ai river villages of Sarawak. Southeast Asian J Trop Med Public Health. 1994;25(3):575-578.

11. Osman A, Khalid B, Tan T, Sakinah O, Wu L, Ng $M$. Endemic goiter and hypothyroidism in Orang Asli and Malays in Peninsular Malaysia. Med J Islam Repub Iran. 1995;9(May):19-25.

12. Othman NH, Omar E, Naing NN. Spectrum of thyroid lesions in Hospital Universiti Sains Malaysia over 11-years and a review of thyroid cancers in Malaysia. Asian Pacific $J$ Cancer Prev. 2009;10(1):87-90.

13. Department of Statistics. Population and Housing Census of Malaysia 2010. Dep Stat Malaysia. 2011:77. doi:10.1007/s13398-0140173-7.2

14. World Health Organisation. WORLD HEALTH SURVEY C-Appendices (KISH tables, Vignettes, Cards. 2002.

15. World Health Organisation. Goitre as a determinant of the prevalence and severity of iodine deficiency disorders in populations. 2014:14-19.

16. WM WN, S R. Malaysia needs universal salt iodinization.pdf. 2010:8-9.

17. Selamat R, Wan Mohamud WN, Zainuddin AA, Rahim NSCA, Ghaffar SA, Aris T. lodine deficiency status and iodised salt consumption in Malaysia: Findings from a national iodine deficiency disorders survey. Asia Pac J Clin Nutr. 2010;19(4):578-585.

18. Jiang $\mathrm{H}, \mathrm{Tian} \mathrm{Y}$, Yan $\mathrm{W}$, et al. The prevalence of thyroid nodules and an analysis of related lifestyle factors in Beijing communities. Int $J$ Environ Res Public Health. 2016;13(4):1-11. doi:10.3390/ijerph13040442
19. Reiners $\mathrm{C}$, Wegscheider $\mathrm{K}$, Schicha $\mathrm{H}$, et al. Prevalence of Thyroid Disorders in the Working Population of Germany: Ultrasonography Screening in 96,278 Unselected Employees. Thyroid. 2004;14(11):926-932. doi:10.1089/ thy.2004.14.926

20. Vanderpump MPJ. The epidemiology of thyroid disease. Br Med Bull. 2011;99(1):39-51. doi:10.1093/bmb/ldr030 